\title{
Ruský konzervatismus přelomu 19. a 20. století
}

\section{Russia Conservatism at the Turn of the 19th and 20th Centuries}

Radomír Vlček / vlcek@brno.avcr.cz

Historický ústav, Akademie věd České republiky, v. v. i., pobočka Brno, CZ

\begin{abstract}
This study focuses on the issue of Russian conservatism at the turn of the 19th and 20th centuries. The author works in a multifaceted way with Alan Sked's work on British conservatism in the early 19th century and points out that the conclusions which Sked outlined for the British setting can also to some extent be applied elsewhere, specifically to the setting of the Russian Empire.
\end{abstract}

\section{Keywords}

Tsarist regime, Russian conservatism, autocracy, sobornost, Alexander II, Alexander III, Konstantin Petrovich Pobedonostsev, Vyacheslav Konstantinovich Pleve, Alan Sked 
Obraz Ruska přelomu 19. a 20. století je nepochybně zajímavý. Na jedné straně spatřujeme Rusko carské, samoděržavné, konzervativní a tradicionalistické, holedbající se konstantami vývoje, na straně druhé Rusko politicky, hospodářsky i sociálně zaostalé, toužící po změnách, po reformách i radikálních krocích. Rusko vidíme na jedné straně mystické a dobromyslné, pohostinné a vstřícné. Ale na druhé straně Rusko nedůvěřivé, odtažité i kruté. Propast, která existovala mezi „dvěma“ Rusky - Ruskem tradičním a oficiálním a Ruskem proměnným a toužícím po dalších změnách -, propast, která rozhodně nebyla výsadou přelomu 19. a 20. století, nebyla nepřekonatelná. To si uvědomovali jak soudobí ruští politici, tak ruská inteligence i některé další vrstvy ruské společnosti. Drtivá většina úvah, jak překonat tyto rozdíly, jež způsobovaly ruské zaostávání za ostatním světem i obraz ruské zaostalosti, směřovala více či méně $\mathrm{k}$ reformám. Ne vždy však reformám za každou cenu modernizačním. Některé vize se opíraly o tradiční Rusko a o návrat k tomu, co je tradičně označováno za Svatou Rus. Nicméně mezi úvahami o nutných změnách vynikali političtí a národohospodářští reformátoři typu Sergeje Ju. Witte (1849-1915) a Pjotra S. Stolypina (1862-1911), kteří ukazovali jako jednu z možných, pro Rusko patrně nejoptimálnějších cest, liberalizaci a jistou míru demokratizace. ${ }^{1}$ I přes tuto vcelku nadějnou alternativu, která se dokonce dočkala v celkovém obrazu Ruska pozitivních dopadů, spěl vývoj Ruska na přelomu 19. a 20. století mílovými kroky k totální revoluční devastaci. Mohli bychom říci, že výše zmíněná propast vedla - i přes pokusy ji obejít „obě výše zmíněné země“ možná pomalými, ale stále zřetelnějšími kroky k dramatickým změnám, které pak uvodila revoluce roku 1917, jež ve své tzv. říjnové fázi ovlivnila negativním způsobem osudy miliónů lidí na několik následujících desítiletí (pokud neovlivňuje značnou část lidské populace, nejen v samotném Rusku, dodnes). ${ }^{2}$

Alan Sked se ve své práci o britském konzervatismu začátku 19. století zamýšlí výhradně nad myšlenkovým světem západní Evropy. Dospěl svými úvahami vloženými do historických souvislostí k mnoha cenným závěrům. Mým cílem není s nimi polemizovat či ukazovat, že platí obecně, ale upozornit na fakt, že závěry, které nastínil A. Sked pro britské prostředí, lze do jisté míry aplikovat i jinde. Následující text si neklade za cíl vyzdvihnout východoevropské prostředí a tvrdit, že Východ a Západ jsou totéž. Je pouze snahou ukázat, že tendence podobné těm, které se odvíjely v západoevropském prostředí, a to i v rámci světového myšlenkového konzervativního světa, se prosazovaly i směrem, u kterého bychom to patrně neočekávali či dokonce ani nepředpokládali. Učebnice nás přece vedou k závěru, že Východ se ubíral jinými cestami než Západ, že pro Východ nelze aplikovat paradigmata vlastní Západu - a tudíž že tyto dva světy, Západ a Východ, mají k sobě nesmírně daleko. Mým cílem je ukázat nebo aspoň naznačit, že tomu tak patrně není. Jistě nelze vše, co probíhalo na Západě, aplikovat na Východ a obráceně. Ale nepochybně se některé procesy odehrávají podobně. Možná, že je odlišuje čas, ve kterém probíhají, či je vzdaluje jistý, často nejen myšlenkově nepřekonatelný geografický prostor.

1 Srov. Vlček, Radomír: S. Ju. Witte a jeho pokusy o prěkonáni krize ruského impéria. Slovanský přehled 81, 1995, s. 289-304; Týž: Liberálni opozice a cesta Ruska ke konstitučni monarchii. (Ke genezi prvního zasedání ruské státní dumy.) Slovanský přehled 82, 1996, s. 229-250.

2 Srov. Hanuš, Jiří - Vlček, Radomír: Vladimír Iljič Lenin: Kontinuita či diskontinuita dějin? Brno 2013, s. $5-13$. 
Z toho pak plyne ono časté - a nejde pouze o aktuální názory - vydělování Ruska a celé východní Evropy z kulturně civilizační dimenze, kterou určuje západní Evropa, přesněji paradigma Západu ve svých širších souvislostech. ${ }^{3}$

Ruský konzervatismus má patrně podobné kořeny jako ten britský. Vliv Velké francouzské revoluce se sice v př́padě ruské společnosti neprojevil tak bezprostředně jako ve společnosti britské, ale i v ní strach z „nakažení“ dramatickými revolučními pochody sehrál tak velkou roli, že vedl mezi některými intelektuály $\mathrm{k}$ vizi nutného konzervování tradic a k budování změn jen a pouze na jejich základě. Dvorní historiograf cara imperátora Alexandra I. Nikolaj M. Karamzin (1766-1826) ve svém pojednání O starém a novém Rusku dưrazně varoval panovníka před liberalizujícími změnami, s nimiž Alexandr sympatizoval již od doby svého carevičování. Liberalizující názory Speranského, směřující k reformě ruských politických institucí a tím narušující tradice samoděržavného systému, se mu jevily jako větší hrozba, než četné radikálně revoluční protesty proti modelu nevolnictví. Podobně jako tvưrci britského konzervatismu se i Karamzin zamýšlel nad nutností pevného silného státu. Jako historik prokázal zejména ve svých objemných $D e ́-$ jinách ruského státu, že síla monarchie je zárukou úspěšného rozvoje Ruska, schopnosti jeho obrany proti uchvatitelům i posilování jeho vlivu vůči soupeřům.

Na rozdíl od britského politického modelu rozřešila dilema mezi rodícím se konzervativním a liberálním myšlením jediná osobnost: car. Soustředěním se na expanzi, k níž mu vytvářelo výborné podmínky napoleonské období, jako by odvedl pozornost od vnitřního Ruska, kterému dal vizi o jistotě spočívající právě ve velikosti a slávě údajně nezpochybnitelného multinacionálního celku. Uzavření Ruska do sebe, zabránění pluralitě názorů (a to i uvnitř perlustrované vládnoucí elity) zamezilo dalšímu propracování konzervativních a liberálních vizí. Zatímco se v britském prostředí konzervatismus proměňoval vlivem aktuální politiky, jak ukazuje A. Sked ve svém příspěvku, ruská aktuální politika zcela vylučovala, že by se její myšlenkový svět, analogický britskému konzervatismu, mohl proměňovat. Jenomže jak ukazuje dlouhodobá historická zkušenost, takovýto postup nelze udržet "na věky“. Sám sebe začne v určité fázi narušovat či dokonce ničit. Ruské prostředí 19. století je toho nejvýraznějším příkladem. Soustřed’me se proto v dalším popisu na Rusko, které jsme naznačili v úvodu - na Rusko, kdy se zcela zřetelně ukazovalo, že postaru se v něm žít nedá. Nechci opakovat patrně známé reálie o Rusku tohoto období, ale přece jen si dovolím připomenout, že poslední dva ruští carové, car imperátor Alexandr III., který vládl Rusku v letech 1881-1894, a car imperátor Mikuláš II., jenž stál v čele ruské říše v letech 1894-1917, dostali - stejně jako lidé kolem nich - v průběhu své vlády vícero jasných náznaků (pro leckterou událost by byl tento výraz přemrštěně skrupulózním vyjádřením toho, jak probíhaly a oč usilovaly), které je $\mathrm{v}$ jednotlivostech i v celku varovaly, že v ruském státě a dokonce i v celé ruské multinacionální společnosti není všechno tak idylické, jak by si představovali a hlavně, jak by si přáli. Můžeme si dokonce položit otázku, jak je možné, že se mohli přes časté stávky studentů a dělníků, projevy nespokojenosti rolníků, prohru ve válce s Japonskem (roku 1905), Krvavou neděli v lednu 1905 a revoluční události let 1905-1907 stále a zarytě držet

3 Srov. Vlček, Radomír: Rusko a Západ. Ke kulturně civilizačnímu dilematu 19. století. In: Dějiny kultury a civilizace Západu v 19. století. Brno 2002, s. 142-172. 
svých dávno již přežitých archaických vizí o tradičním Rusku a jeho vnitřně podmíněné mentální (duchovní) neměnnosti. Vysvětlení toho se však zdá poměrně jednoduché. V podstatě vše skrývá tzv. uvarovská triáda a stěžejní kořen tvoří tzv. sobornost. Triáda byla zformulována ve třicátých letech 19. století jako reakce na děkabristické povstání a následnou snahu některých ruských intelektuálů, tzv. raznočinců, modernizovat ruský myšlenkový svět odkazem na formující se západoevropský liberalismus a konzervatismus, tehdejším ruským ministrem osvěty Sergejem S. Uvarovem (1786-1855) do oficiální direktivy: jednota pravoslaví, samoděržaví a národnosti je v Rusku nadevše a všechno se jí musí v Rusku řídit. V ruské tradiční představě, odvolávající se na dřívější již zmíněnou tzv. sobornost, šlo o nerozbornou duchovní jednotu ruského cara a jeho lidu, odvíjející se od víry v nejvyššího, zprostředkovávané ruskou pravoslavnou církví. Jednalo se o víru v cara jako zosobnělého Boha na zemi, který sice není omezen žádnými světskými zákony či státní byrokracií, ale (nebo právě proto) vládne ruské zemi podle svého osobního zaujetí, plné oddanosti a vlastní božské inspirace, tedy za všech okolností spravedlivě. Se svým pravoslavným, věrným lidem, který ho za to miluje a ve všem poslouchá jako ctěného otce (akronym „car - batuška“, podobně jako v 18. století, kdy Rusku několikrát vládly ženy, termín „carevna - matuška“), je vysloveně mysticky spojen. Nic se tedy nemá měnit, v Rusku vše určuje car, a pokud se Rusko přesto má (a vlastně musí) vyvíjet, pak se tak musí dít jen zásahy shora, tedy rozhodnutím panovníka. Rusko je tradiční, neměnné, a tedy pevné a kamenné.

Paradoxní je, že tento tradiční model vlády, o nějž se sebevíce snažili i poslední Romanovci, nakonec přivedl Rusko k totálnímu kolapsu. Rusko a jeho vládnoucí dynastii totiž mohla zachránit jedině včasně a dobře provedená reforma. At̉ již, jak naznačuje Sked pro britské prostředí, v konzervativní nebo liberální podobě - ale nikoli revoluce, jak se snažili prosadit (a nakonec, bohužel, prosadili) radikálové. Inspirace i zkušenosti Západu byly v tomto směru obrovské. $\mathrm{V}$ ruské historiografii, která zejména v posledních letech adoruje liberální myšlení, se zdůrazňují vlivy západoevropského liberalismu a ruské myšlení 19. století je často popisováno jako snaha leckterých ruských intelektuálů nabídnout řešení právě podle tohoto modelu. Časté je tvrzení, že pro Rusko bylo osudné, že poslední ruští carové a politici kolem nich o celkovou reformu využívající liberální podněty nestáli a stále umíněně, navzdory nárůstu liberální a radikální opozice, směřovali ke své vysněné tradiční představě samoděržaví. Nikoli však ke konzervativnímu postupu, jak by se mohlo zdát při využití některých analogií uváděných Skedem. Jak výstižně napsal jiný britský historik Orlando Figes (*1959): „Jejich tragédií bylo, že zatímco Rusko stálo na prahu dvacátého století, oni se ho snažili vrátit do století sedmnáctého. ${ }^{* 4}$

Posuneme-li Figesovu myšlenku do prostředí celé ruské společnosti, pak jistě neudiví konstatování, se kterým se můžeme setkat často, tedy že mentalita ruského lidu se od středověku nikterak neměnila. Rolníci, kteří tvořili drtivou většinu ruské společnosti, se stále drželi každodenních patriarchálních zvyklostí. ${ }^{5}$ Vytvářeli a drželi se toho, co by-

4 Srov. Figes, Orlando: Lidská tragédie. Ruská revoluce 1891-1924. Praha - Plzeň 2000, s. 43.

5 Srov. Pipes, Richard: Rusko za starého režimu. Praha 2004, s. 179-213. 
chom mohli označit za ruský svéráz. ${ }^{6}$ Ale přece jen něco uvnitř ruské společnosti nebylo neměnné. Elita ruské společnosti, která se za vlády prvních Romanovců v 17. století alespoň zčásti seznámila s jiným než ruským kulturně civilizačním světem, začala žít podle západního stylu. Nebylo v tom bytostné přesvědčení, že se Rusko musí změnit podle západního vzoru. Jednalo se o snahu, jiným způsobem života, jiným jazykem a jinými zvyky se zřetelně odlišit od prostého lidu. Ukázat vznešenější způsob života, jinou komunikaci, jiné myšlení. Ale zájem o Západ, at̉ již zprostředkovaný bud’ cizinci přijiždějícími do Ruska, nebo cestami Rusů do ciziny, byl už nastartován - a Rusku se tak nabízel západní myšlenkový svět se všemi svými podněty a inspiracemi.

Nelze neupozornit na skutečnost, že odlišnost způsobu života elity ruské společnosti a širokých mas se vzápětí stala na dlouhou dobu kruciálním problémem Ruska. Dokonce by bylo možné tvrdit, že v ní spočívaly kořeny dramatu ruské sociální revoluce, ke kterým se záhy přidružila další komplikace: vzrůstající konflikt mezi tou částí společnosti, která byla stále vzdělanější a Západem poučenější, a mezi zkostnatělou autokracií, jež nechtěla připustit sebemenší změny. Vrátíme-li se k meritu naší úvahy, řekneme ani liberální ani konzervativní. A to i přesto, že se v podstatě ilegálně v průběhu 19. století formovaly skupiny, které bychom mohli definovat jako liberální na straně jedné a tradicionalistické a konzervativní na straně druhé. Protože nás zajímá především jejich konzervativní část, zdůrazněme, že ani konzervativci nechtěli ponechat Rusko zkostnatělé a neměnné. Chtěli jej reformovat, ale podle zásad konzervatismu. Tedy tak, jak na ně upozornil ve svém textu Alan Sked. Pochopitelně, v Rusku se vždy vše přetvářelo do zvláštní, typicky ruské mentální podoby. Nelze tedy jednoznačně aplikovat metody a formy britského (západoevropského) konzervatismu na ruské prostředí. Ale mnohé lze identifikovat jako inspirace a podněty. A to dokonce, jak vzápětí uvidíme, i v politické praxi. Tedy nejen konzervativní politické myšlení, ale i konzervativní politická praxe. Ruští konzervativci, jež o sobě dali jednoznačně vědět ve druhé polovině 19. století, dostali-li slovo, důsledně a někdy snad až represivně bojovali s vizemi demokracie a národní svobody, které jim asociovaly změny, jimiž Rusko zejména v šedesátých a sedmdesátých letech 19. století prošlo. Byli přesvědčeni, že alfou a omegou řešení všech ruských problémů je to, aby Rusko bylo skutečně ruské, a to jak ve své národnostní, tak i pravoslavně věroučné „svaté" tradici. Především v těchto oporách spatřovali jistotu propojení minulosti se současností i záruky optimálního vývoje. Další jejich konzervativní projevy s tím bezprostředně souvisely - především jejich boj proti liberálnímu ekonomickému uvolnění. Podobně, jak ukázal Sked na příkladu Burka, bychom mohli být přesvědčeni (přičemž těchto analogiî by bylo možné uvést nespočetně více), že vláda málo majetných či nemajetných by v Rusku znamenala nejen okrádání těch, kdo majetek měli, ale především anarchii v loupení a vraždění.

Už jsem naznačil, že v Rusku se již na počátku 19. století vytvořila vrstva intelektuálů, která postupně ovlivňovala veřejné mínění a rodila bojovníky proti byrokratickému policejnímu řádu (děkabristé, raznočinci, radikální demokraté). Reformy Alexandra II. ruskou inteligenci ještě více zaktivizovaly. Hladomory, které nastaly v devadesátých letech

6 Srov. Rutheford, Edward: Russka. Román o Rusku. Praha 2002, s. 9-10, 691-700. 
19. století, ji pak zpolitizovaly. Liberální inteligence začala díky tomuto vlivu vidět problémy dělníků a rolníků, utrpení vesnice, stoupající násilí a jako reakci na ně státní represe. $\mathrm{S}$ tím vším se rozhodla bojovat, nebot neviděla jinou cestu než razantní změnu. A tak se stalo, že od devadesátých let 19. století směřovali liberálové a socialisté společně k radikálnímu zvratu, který měl přinést politickou reformu státu a všech rovin jeho činnosti. V ř́jnu 1905, poté, co Rusko od počátku roku zavalila vlna lidových bouří, car Mikuláš II. ustoupil a povolil reformy, jejichž výsledkem měla být změna Ruska v konstitučně absolutistický stát. Jenomže reformy byly pro svoji dobu polovičaté. Rusko potřebovalo skutečnou demokratickou změnu a ta se neodehrála. Bylo proto přirozené, že společnost se dále radikalizovala. Revoluce zmíněnými reformami neskončila. A právě na tomto místě se nabízí možná nehistorická otázka, zda pro Rusko nebyla v této fázi vývoje použitelnější jiná alternativa vývoje: cesta konzervativních proměn, tak jak ji hájil ve Velké Británii Burke a jak se o ně britský konzervatismus snažil po celé 19. století. Tedy to, co naznačuje, na co upozorňuje a co vysvětluje ve své práci Alan Sked. Byl by to však začátek onoho moderního konzervatismu, jak se o něm zmiňuje Sked? Podle (nejen) jeho přesvědčení je kořenem moderního konzervativního myšlení revoluce. Revoluce se svými politickými, ekonomickými i sociálními aspekty. V Rusku se takováto revoluce skutečně odehrála až v roce 1905, resp. v letech 1905-1907. Neexistovalo ale v Rusku již dř́ive něco, co moderní konzervatismus formovalo? Výše jsem upozornil na Karamzina a na skutečnost, že i přes maximální snahu ruských carů 19. století bránit rozvoji politického a společenského myšlení se názory, podobné západoevropskému konzervatismu, objevovaly. Je nesporné, že v Rusku na přelomu 19. a 20. století existovaly osobnosti, které v konzervativním pohledu - nikoli nepodobném britskému konzervatismu počátku 19. století - nacházely řešení ruské krize. Jiné řešení, než jaké nabízeli liberálové nebo radikální demokraté. Připomeňme si proto dvě nejvýznamnější z nich: Konstantina Petroviče Pobědonosceva (1827-1907) a Vjačeslava Konstantinoviče Pleve (1846-1904). Nepochybně se totiž řadí mezi nejznámější a nejvlivnější představitele ruského konzervativního myšlení a dokonce i ruské konzervativní politiky 19. století.

Svou hlavní politickou kariéru oba zahájili a do popředí politické činnosti se dostali po roce 1881, tedy po nástupu cara Alexandra III. k moci. Ten se ocitl na ruském trůně druhý den po smrtelném atentátu na jeho otce, cara-reformátora (označovaného někdy kvůli zrušení nevolnictví též jako car-osvoboditel) Alexandra II. (vládl 1855-1881). Alexandr III. - ačkoli bylo tradicí přihlásit se $\mathrm{k}$ odkazu svého předchůdce - krátce po svém nástupu na trůn změnil státní politický kurs, odsoudil reformy svého otce, které podle něj byly unáhlené a neučinily nic jiného, než že zradikalizovaly ruský lid, a přiklonil se ke konzervativní politice svého děda, cara Mikuláše I. (vládl 1825-1855). S vládou Alexandra III. tedy skončilo nepř́iliš dlouhé reformní, „liberální“ období. Došlo k utužení samoděržavného režimu, dřive zavedené reformy byly omezovány a redukovány. Iniciátorem a ideologem tohoto kurzu se po roce 1881 stal nejen car, ale i několik jeho poradců, mezi něž patřili novinář konzervativního smýšlení Michail N. Katkov (1818-1887), ministr národní osvěty a nejvyšší prokurátor Svatého synodu v letech 1865-1880 Dmitrij A. Tolstoj (1823-1889) a v neposlední řadě již zmínění Konstantin P. Pobědonoscev a Vjačeslav K. Pleve. Co měly tyto osobnosti společného? $\mathrm{V}$ prvé řadě nedůvěru $\mathrm{k}$ reformám, zaváděným $\mathrm{v}$ šedesátých 
a sedmdesátých letech 19. století. Nikoli však proto, že by tyto reformy principiálně odmítaly, jak se většinou uvádí, ale proto, že je považovaly za nevhodně načasované. Alexandr II. je totiž podle jejich názoru vyhlásil pod „revolučním“ tlakem. Rusko bylo dle jejich názoru po porážce v krymské válce hmotně i duchovně zdevastované a potřebovalo se nejprve postavit znovu na nohy, stát se hospodářsky a zejména mentálně silným celkem, schopným konkurovat tehdejším mocným evropským státům. Nešlo tedy o to, aby podlehlo tlaku západní Evropy (ten byl vskutku jasně vyjádřen v závěrech Pařŕžské mírové dohody, podle níž se Rusko ke změnám zavázalo). Protože se ale podle jejich mínění po hlavě vrhlo do reforem, nastala anarchie, která vedla k radikalizaci společnosti. Jejím vyvrcholením se stala řada atentátů jak na samotného „Osvoboditele“, tak na další čelné představitele ruského státu. Důvodem odporu zmíněných konzervativců tedy nebyl pouze strach z podobného nebo i horšího osudu, jaký potkal Alexandra II., ale také strach z toho, že se Rusko radikalitou reforem přiblížilo k revolučnímu procesu, který zásadním způsobem přeměnil etické hodnoty společnosti. Osudu nikoli pro jednotlivce, ale pro Rusko jako celek. Ruští konzervativci - a v tom je nepochybná analogie se Skedovým popisem britského prostředí - zastávali přesvědčení, že reformy v Rusku, tak jak byly v šedesátých a sedmdesátých letech 19. století provedeny, nevěstily nic dobrého. Jaké z toho plyne východisko? Ruští konzervativci nebyli fatalisté, nebot’ navrhovali cestu. A opět nikoli nepodobnou té někdejší britské: podle zmíněných ruských konzervativců bylo nutné se vrátit k uvarovské triádě a v ní vyjádřené jednotě samoděržaví, pravoslaví a lidovosti. Byli totiž přesvědčeni, že to je skutečný pilî́r ruského impéria. Pevný silný všemocný stát. Bylo-li od této hodnoty Alexandrovými reformami částečně upuštěno, byla to chyba, kterou však ještě bylo možno napravit. A tak chválili a ve své praktické činnosti také mohutně podporovali, když se Alexandr III. k vizi triády jako stavebního kamene ruského státu po roce 1881 přihlásil. Samoděržaví bylo podle konzervativců ve stávajícím čase (!) jediný možný způsob vlády nad Ruskem. Proč? Protože ruský lid je na něj a na osobnost cara zvyklý, samoděržaví je v jednotě s vírou a lidem zakořeněno, a lid si ho proto jako způsob vlády bytostně přeje. Víru nelze odtrhnout od pravoslaví, ruského pravoslaví, které je jako jediné náboženství Ruska se silně nábožensky založeným národem historicky svázané. A ruský národ, lid podřízený principům samoděržaví a pravoslaví je pevným základem, který je třeba rozvíjet, reformovat, ale jen tak, aby se nenarušovala struktura státu. Přitom ovšem u ruských konzervativců došlo ke zdůraznění ruského národa jako jedině svébytného a dramaticky odlišného od ostatních evropských národů, dokonce nadřazeného ostatním národům ruského impéria. Uvarovská triáda vyjadřovala svébytnost ruského impéria. Konzervativci jejím prostřednictvím stavěli do popředí Rusko odlišné od jiných národů Evropy. Nebránili se některým neruským vlivům, ale podle jejich mínění Rusko nemohlo (a nesmělo!) pouze přejímat evropské myšlenky a hodnoty. Evropské hodnoty přece nejsou stavěny pro ruský národ. Ruští konzervativci ovšem vskutku západními myšlenkami neopovrhovali. Naopak. Byli bytostně přesvědčeni, že je nutné vychovat a vzdělat ruský národ a západoevropské konzervativní myšlenky pro něj přetransformovat tak, aby byly pro něj pochopitelné a přijatelné. Hlavně je nutné na ně Rusko připravit.

Do takto koncipované konzervativní ideologie se dokonce promítlo i něco dalšího z tradičního Ruska - myšlenka Moskvy jako „třetího Ř́ma“. Souviselo s přesvědčením, 
že Moskva má vedoucí postavení v pravoslavném, tedy jediném opravdově křestanském světě. To pak vedlo (a v pojetí konzervativců vskutku mělo vést) u etnicky ruských obyvatel k podcenění sousedních národů, západního světa i jakékoli jiné než pravoslavné církve. Pravoslavná církev podle ruských konzervativců musí být bytostně spojena se státem a carem a ten naopak musí být nerozborně spojen s ní. Car existuje pouze z milosti Boží, je zástupcem Boha na zemi. Z toho vyplývá i to, že Bůh přikazuje ruskému lidu poslouchat cara.

Konstantin P. Pobědonoscev (1827-1907) měl vliv na ruskou politiku v letech 1881 až 1905. Byl vynikajícím právníkem, státníkem a rádcem ruských carů počínaje Alexandrem II. Byl velmi vzdělaný, po studiích práv v Sankt-Petěrburgu působil od roku 1860 jako profesor občanského práva na Moskevské státní univerzitě a zároveň vykonával důležitou funkci státního úředníka v Senátu. Roku 1861 ho povolal Alexandr II., aby se stal učitelem a vychovatelem následníka trůnu, carova prvorozeného syna Mikuláše. Pobědonoscev se kvůli tomu vzdal profesorské kariéry na Moskevské univerzitě a roku 1865 se stal „jen“ jejím emeritním profesorem. Ve stejném roce však následník trůnu Mikuláš zemřel. Pobědonoscevova kariéra vychovatele tím však neskončila: stal se vychovatelem dalšího následníka trůnu, Alexandrova stejnojmenného syna, budoucího cara Alexandra III. Od té doby s ním byl v kontaktu až do jeho předčasné smrti roku 1894.

Podotkněme, jak to $\mathrm{v}$ jiných případech podobně činí Sked pro britské prostředí, že budoucí car Alexandr III. ani jeho vychovatel Pobědonoscev svými názory nevzešli z konzervatismu. Trefné je spíše konstatování, že se konzervatismu naučili. Začali totiž k němu inklinovat až po neúspěšném (prvním) atentátu na Alexandra II., provedeném studentem Dmitrijem V. Karakozovem (1840-1866) roku 1866. Pobědonoscev se teprve tehdy stal neúprosným obhájcem samoděržaví jako jediného způsobu vlády, který zaručí Rusku klid. Tento názor pak prohluboval a konkretizoval v celé své další kariéře. Roku 1868 se stal senátorem, o šest let později členem Státní rady. Vrchol jeho kariéry přišel s jeho jmenováním vrchním prokurátorem Svatého synodu, a to roku 1880. V jeho čele totiž zůstal plných dvacet čtyři let, až do roku 1905, kdy byl z této funkce v důsledku revoluce carem odvolán.

V období vlády Alexandra III. a zčásti i za doby vlády Mikuláše II. byl tedy Pobědonoscev vlastně hlavou ruské pravoslavné církve a zároveň nejprominentnějším mužem stojícím vedle samotného cara. Mužem, jehož názory se zejména car Alexandr III. maximálně řídil. Pro formování ruského konzervativního myšlení je jistě signifikantní, že carským manifestem z 29. dubna 1881, napsaným osobně Pobědonoscevem, se car Alexandr III. oficiálně přihlásil k uvarovské triádě. Pobědonoscev byl i vychovatelem budoucího Mikuláše II., ve kterém však neviděl silného panovníka. Ruský historik Edvard Radzinskij ( * 1936) v díle Posledni car Pobědonosceva charakterizuje jako „vyschlého staříka s odstátýma ušima a se sípavým dechem velkého inkvizitora, ztrápeného věčným půstem. "7 Podstatnější než tento čtenáři podsouvaný odpudivý obraz konzervativce je ovšem fakt, že Pobědonoscev se díval stále více kriticky na reformy z šedesátých a sedmdesátých let 19. století. Reformy, které za jistých okolností mohly být předzvěstí svobody a občanských práv. V nástupní řeči prý Pobědonoscev prohlásil, že Rusko je „zvláštní země, kde všech-

7 Srov. Radzinskij, Edvard: Posledni car. Praha 1993, s. 21. 
ny reformy i svoboda slova vždycky skončí rozvratem."8 Jako největší moc proti revoluci a terorismu - obojí musí být vypáleno „železem a krvi““ - proto stavěl jedině mocné a nezpochybnitelné samoděržaví. A aby bylo samoděržaví stále silné, hledal a zdůvodňoval jistotu jeho instituce, tedy státu. Významným dílem o státu a Pobědonoscevově doktríně pevného samoděržaví se stal jeho Moskevský sbornik z roku 1896. Ke konstituci, demokracii, parlamentarismu, občanským právům, rovnosti, svobodě jednotlivce a dalším západním inovacím se v něm postavil jednoznačně kriticky. Slavnými se zde staly jeho výroky, ve kterých tvrdil, že parlamentarismus je „největší lež naší doby“, a volební právo „osudným bludem“. ${ }^{9}$ Demokracii považoval za „nesnesitelnou diktaturu prostého, nevzdělaného lidu“. ${ }^{10}$ Stejně negativně se stavěl i ke svobodnému tisku, který nazýval „nejprolhaněǰ̌î institucí“. Novináŕi prý s lidem manipulují a vnucují mu své vlastní myšlenky, kterým prostý lid nerozumí a snadno se proto jimi nechá ovlivnit.

Pobědonoscev kriticky přistupoval k Západu, jehož civilizaci ve stávající podobě považoval za zhoubnou. V aktuální Evropě spatřoval ztělesnění anarchie, kdežto Rusko vnímal jako zosobnění pořádku. Stávající Evropa pro něj byla smrt, kdežto Rusko život. Nikoli pro jeho samotnou podstatu, ale proto, že v Evropě sílilo liberální a revoluční hnutí. V Rusku tomu od devadesátých let 19. století bylo podobně, ale Pobědonoscev zastával bytostné přesvědčení, že jde pouze o exces, který se podaří tradicionalismem a konzervatismem utlumit. Tento jeho postoj prokazuje již skutečnost, že pod vlivem Pobědonosceva odmítl nově nastupující Alexandr III. návrh Lorise-Melikova z roku 1881, již podepsaný Alexandrem II. (těsně před jeho smrtí), podle kterého by došlo ke zřízení dvou komisí (správně-hospodářské a finanční), jež měly připravovat návrhy na reformy guberniální správy, daňového systému, výkup selské půdy aj. Tento návrh mohl vést od byrokratické správy, jež jako jedinou uznával Pobědonoscev, k účasti některých společenských vrstev na státní správě. I když neměla ona myšlenka nic společného s konstitucionalismem, mohlo jít o významný politický krok, protože podíl alespoň některých společenských vrstev na státní správě by je formoval, učil prosazovat své návrhy, získávat zkušenosti, uvažovat o parlamentarismu, což ovšem bylo v př́íkrém rozporu se státní ideologií, jež se prosazovala díky konzervativcům již ke konci života Alexandra II.

Pobědonoscev si svůj vliv zachoval i v prvních letech vlády Mikuláše II. Podobně jako v případě Alexandra III. byl autorem i jeho nástupnického manifestu. Car v něm reagoval na očekávání přeměny politického kurzu Ruska směrem ke konstituční monarchii. Neoblomně všechny naděje vyvrátil a přihlásil se k následování svého otce Alexandra III. Mikuláš se cítil povinován následovat závět svého otce, kterou odsuzoval všechny reformy Alexandra II. Zachováno mělo být samoděržaví jako ruská historická vládní forma. Hájil tezi, že jestliže samoděržaví padne, Rusko se ocitne v občanských válkách a revolucích. Samoděržavný car je odpovědný za osud svých poddaných, základem života mu musî být víra $\mathrm{v}$ Boha a posvátná carská povinnost. $\mathrm{V}$ zahraniční politice pak nabádal nevěřit

8 Srov. tamtéž.

9 Srov. Švankmajer, Milan - Veber, Václav - Sládek, Zdeněk - Moulis, Vladislav: Dějiny Ruska. Praha 2002, s. 278 .

10 „The insupportable dictatorship of vulgar crowd“. Srov. http://en.wikipedia.org/wiki/Konstantin_Pobedonostsev. Staženo 16. 7. 2014. 
nikomu, zůstat nezávislý a hlavně udržet Rusko stranou válek. Základ státu viděl v rodině a pravoslavné církvi, které je potřeba ochraňovat. První léta vlády Mikuláše II. tak byla mnohými historiky popravdě nazývána „léta Pobědonoscevova“ či „Pobědonoscevovo Rusko“. Ztráta jeho vlivu a postupné odcizení s carem nastaly až počátkem 20. století, aby vyvrcholily roku 1905 carovým vydáním Ǩíjnového manifestu a Pobědonoscevovým odvoláním z funkce vrchního prokurátora Svatého synodu a zbavením politického vlivu. Ale až do tohoto okamžiku byl jeho vliv na celé Rusko stále značný, což dokazuje i to, že roku 1905 byly na jeho návrh na několik měsíců uzavřeny všechny ruské univerzity, protože byly považovány za „ústředí revolučního kvasu a propagandy."11

V Pobědonoscevově pojetí byla zdůrazňována ruská etnická národnost a ruské pravoslaví ve spojení s netolerancí vůči jiným národnostem (např. tvrdý postup vůči Finům, Polsku, Ukrajině aj.), jiným vyznáním, a zejména s antisemitismem. Pobědonoscev byl zodpovědný za různou míru vládního šikanování a pronásledování jinorodců i jinověrců, at již šlo o jakékoli neruské národnosti nebo to byli katolíci, protestanté, židé, starověrci či jiné směry. V průběhu vlád Alexandra III. i Mikuláše II. se v Rusku Pobědonoscevovým přičiněním uskutečnila řada pogromů na Židy. Viníci byli málokdy potrestáni, na mezinárodní protesty bylo odpovídáno tak, že se jednalo o potrestání běžné kriminální činnosti a náboženská nesvoboda byla popírána. Často byl náboženský útlak součástí poruštování neruských území (Pobaltí, Arménie). Podle oficiálního stanoviska bylo Rusům vlastní pravoslaví, jiná vyznání se zahrnovala mezi zhoubné vlivy evropského západu. Celých $98 \%$ z 5.2 milionu Židů muselo žít ve vyhrazených guberniích na západě říše - tehdy se také poprvé uvažovalo o jejich vysídlení na neobydlené území, přičemž Pobědonoscev navrhoval vytvoření zvláštní židovské kolonie. Židé ovšem, na rozdíl od jiných národností, neměli být rusifikováni, nýbrž donucováni různými formami násilí a státní šikany k odchodu ze země.

Podle nařízení z 1. září 1878 mohli př́íslušníci četnických a policejních sborů zadržet nebo poslat do vyhnanství kohokoli, kdo byl ne jen usvědčený, ale i podezřelý z politických zločinů. Mezi ty se ovšem započítávalo i pouhé vměšování se do politiky, nebot tato sféra byla vyhrazena pouze carské moci. Pověstný byl v tomto smyslu zákon z roku 1845, který měl tak neobyčejně neurčité vymezení politických „zločinů“, že bylo možné do jejich skupiny zahrnout téměř cokoli, např. nedostatek respektu ke státní moci. Takové zákony navíc nerozlišovaly mezi viníky, vedle sebe tak byli stavěni nespokojení občané i vyslovení teroristé. To bylo také umožněno neobyčejnou tvrdostí trestů za „politické zločiny“. Poté, co vyšla na světlo jednoduchost, s jakou se téměř stal úspěšným atentát na cara Alexandra II. v roce 1879 (k jeho zmaření došlo jen náhodou; k tomu, aby bylo pod carskou jídelnu umístěno dostatečné množství výbušnin, stačil atentátníkům jen převlek tesaře), byla následujícího roku 1880 vytvořena vskutku moderní politická policie, jejíž pravomoci doznaly oproti její předchůdkyni - Třetímu oddělení carské kanceláře - značného rozširření. Od roku 1881 bylo navíc četnictvo vyňato z pravomoci gubernátorů a spadalo př́ímo pod řízení ministerstva vnitra. Ve své podstatě to znamenalo, že se mohlo řídit vlastními zákony a zodpovědnost za ně pak nesl policejní ředitel.

11 Srov. tamtéž. 
Vrał̉me se ještě ke skutečnosti, která s Pobědonoscevovým konzervatismem bezprostředně souvisela - k jeho působení na postu vrchního prokurátora Svatého synodu, tedy k roli Pobědonosceva jako hlavy „správní rady“ ruské ortodoxní církve. Pro jeho konzervativní přesvědčení bylo charakteristické, že za dvacet čtyři let působení v této funkci vložil náboženství, výchovu a školství zcela do rukou státu. Svatý synod byl založen Petrem I. roku 1721, aby spravoval státní ruskou pravoslavnou církev a bojoval proti kaciŕství a ateismu. Vrchní prokurátor Svatého synodu (státní úředník a většinou carův důvěrník, jmenovaný zejména z řad vysokých vojenských činitelů či členů byrokratického aparátu) měl bdít nad tím, aby Synod přesně a včas plnil usnesení vládního senátu a úkony cara. Zavedením Svatého synodu byly zlikvidovány zbytky autonomního postavení ruské pravoslavné církve, která se jím dostala pod agendu státní správy. Vrcholu podřízení ruskému státu dosáhla právě za Pobědonosceva. Dosvědčuje to již naznačená skutečnost, že během jeho působení jako vrchního prokurátora Svatého synodu došlo k masivnímu nárůstu počtu škol. Mezi lety 1881-1904 se jejich počet zvýšil ze 4 tisíc na 43 tisíc! Ve farních školách byl učitel jmenován biskupem a polovina výuky byla věnována náboženství. Fakt, že došlo k takovému prudkému rozšíření vzdělání, je samozřejmě chvályhodný, ne už tak ale ostatní Pobědonoscevovy praktiky a negativní postoj k vy̌šímu vzdělání. Pobědonoscev zasahoval a bojoval jak proti katolíkům, tak i protestantům a dalším „mystickým sektám“. Stavěl se proti smíření Vatikánu s Ruskem, dokonce roku 1895 zahájil kampaň na pronásledování katolíků v Rusku. Zní až paradoxně, že v tomto okamžiku zařadil katolíky do protistátní mystické sekce. Jednání s Vatikánem označil za ohrožení ruské samostatnosti a politiky. Snahy o svolání ekumenického koncilu a o usmíření i později v roce 1903 jeho přičiněním Svatý synod odmítnul. Tehdy Pobědonoscev nařkl katolickou církev z agrese a snahy proniknout do ruského světa. Vyhlásil boj proti v jeho očích zpátečnické katolické Evropě a zdůraznil povinnost pravoslavné církve bránit ruský lid proti této církvi. Obdobný postoj zastával i proti protestantům. Židé byli utlačování ještě více. I po roce 1905 pravoslavná církev spolupracovala nadále se státem při potlačování protistátních tendencí. ${ }^{12}$

Vjačeslav K. Pleve byl stejného politického přesvědčení jako Pobědonoscev. Dokonce bychom mohli tvrdit, že tam, kde Pobědonoscev svými konzervativními názory končil a kde mu v jejich dalším rozvoji a praktické aplikaci docházel dech, tam jeho stín překračoval právě Pleve.

Pleve stejně jako Pobědonoscev zažil vládu čtyř carů: od Mikuláše I. přes Alexandra II. a III. až po Mikuláše II. Jeho politické působení lze nejvíce sledovat v době panování cara Alexandra III. a Mikuláše II., tedy v době návratu ke konzervativní samoděržavné politice jejich předchůdce Mikuláše I. Stejně jako Pobědonoscev i Vjačeslav Pleve studoval práva na Moskevské univerzitě. Od roku 1867 pak zastával různé pozice na ministerstvu spravedlnosti a jako náměstek prokurátora působil např́íklad ve Vladimirském obvodu. Od roku 1879 byl činný jako žalobce petrohradské soudní komory, po úspěšném atentátu na Alexandra II. vyšetřoval jeho vraždu a stal se ředitelem Policejního oddělení Ochranky (Státní policie).

12 Srov. Vydra, Zbyněk: Židovská otázka v carském Rusku, 1881-1906. Vláda, Židé a antisemitismus. Pardubice 2006. 
Od roku 1884 byl Pleve členem Senátu a od roku 1885 působil jako náměstek ministra vnitra, v letech 1902-1904 byl ministrem vnitra a velitelem četnictva. Pod jeho pravomoci se tak na počátku 20. století dostaly všechny policejní úřady, byl odpovědný za klid v zemi, ale také za zdravotní a sociální zaopatření, tisk, cenzuru a vězeňství. Z titulu své funkce rovněž řídil záležitosti ostatních církví kromě pravoslavné, která byla v rukou Svatého synodu, tedy Pobědonosceva. Ve funkci ministra vnitra Pleve působil sice jen dva roky, ale jak uvádí historik Richard Pipes, i za tak krátkou dobu se mu podařilo Rusko nejvíce přiblížit policejnímu totalitnímu státu v jeho moderním pojetí. Státní policie v tomto období pronikala do všech sfér ruské společnosti a oblastí života.

Od roku 1899 do roku 1902 Pleve rovněž zastával funkci gubernátora Finska. Do této funkce byl dosazen carem v odpověd' na protesty Finů, nebo spíše jejich pasivní rezistenci a všeobecnou neochotu vstoupit do ruské armády, což jim přikazovala carským manifestem nová finská ústava. Pleve měl ve Finsku sjednat klid. Nezklamal. A to i tím, že zahájil důslednou rusifikační politiku. Na základě Pleveho rozhodnutí bylo úřadům nařízeno jednat ne finsky, ale rusky. Do Finska byli dosazeni ruští agenti, došlo k omezování práv Finů. Pleveho represivní politika vyvrcholila rokem 1901, kdy byla rozpuštěna a zakázána finská armáda.

Pleve ovšem projevoval svůj konzervatismus především prostřednictvím antisemitismu. Vycházel z teze velmi podobné Pobědonoscevovým názorům - Rusko musí být etnicky ruské, etničtí Rusové musejí v něm mít rozhodující slovo. Jen oni chápou, co jejich stát potřebuje v současnosti, jaký byl v minulosti a jaký má být v budoucnosti. Jak prokázal ve své monografii o ruském antisemitismu historik Zbyněk Vydra (*1978), v Rusku krystalizovaly protižidovské tendence již delší dobu. První vlna pogromů přišla v listopadu roku 1881 a trvala do roku 1882. Druhá, o mnoho silnější, proběhla v letech 1903-1906. Zatímco první vlna pogromů v osmdesátých letech 19. století vycházela z tradičních, konzervativních předsudků a nenávisti křestanů vůči Židům, ve druhé vlně na počátku 20. století se již dá hovořit o radikálních projevech antisemitismu, ovlivněných moderním západním antisemitismem Německa či Francie. Pobědonoscev i Pleve byli bezesporu antisemité, ale tradiční - staří antijudaisté (známý je často citovaný Pobědonoscevưv návrh řešení židovské otázky v Rusku, tzv. po třetinách - třetina emigruje, třetina konvertuje a třetina vymře). Oba dva se sice angažovali v židovské otázce a připravovali diskriminační protižidovská zákonná opatření, ale na pogromech jako takových se nepodíleli. Shodně se Z. Vydrou lze konstatovat, že Pobědonoscevův a Pleveho konzervatismus neměl zájem na podobných „excesech“. Konzervativci v pogromech viděli nejen židovskou otázku, ale i otázku revoluční. Pogromy považovali za projev lidského vystoupení, lidové aktivity proti vládě. To je děsilo a jako takové je oficiálně odmítali. Po protižidovských pogromech osmdesátých let dokonce i Svatý synod nabádal k potlačení protižidovských nálad. Při druhé vlně pogromů měl zase ministr vnitra Vjačeslav Pleve zájem na obnovení klidu a pořádku, který pogromy narušovaly. Avšak na druhou stranu Pobědonoscev ani Pleve neudělali nic pro jejich potlačení.

Antisemitismus a tažení proti národnostnímu svérázu velmi úzce souvisely s tím, že Pleve byl podobně jako Pobědonoscev zastáncem př́ísného centralismu, v jehož protikladu působila zemstva, nebot i přes jejich velmi omezené pravomoci byla významným 
faktorem při šíření konstitučních myšlenek a polem pro působení liberálů (vlastně jediným). Proto se snažilo ministerstvo vnitra za Alexandra III. a Mikuláše II. tyto orgány omezovat. Jakožto ministru vnitra podléhal Plevemu oblastní úřad nadřízený instituci zemstev. Pleve sám považoval odborníky nižšího původu pracující v zemstvech za revolucionáře a ministerstvo vnitra a jeho oblastní úřad zemstvům v jejich aktivitách trvale bránily. Oblastní gubernátor, postavený do čela oblastních úřadů, měl právo veta nad jmenováním členů zemstev, financemi i většinou jejich usnesení. Tito gubernátoři jmenovali místní náčelníky, kteří působili jako hlavní carští úředníci na ruském venkově. Byli to většinou příslušníci drobné šlechty, často omezení a nízkých kvalit, přitom však mohli změnit rozhodnutí vesnických shromáždění nebo rozhodovat v právních sporech. V důsledku růstu nespokojenosti vydal car Mikuláš II. 11. března 1903 manifest, v němž proklamoval reformy, mj. v oblasti správy. Poté ustanovil Pleve komisi pro reformu místní správy, a to pouze proto, aby dosáhl zvýšení pravomocí gubernátorů.

Na počátku 20. století se Pleve snažil vypořádat jak s nepokoji na venkově (projevovaly se ve značné míře již v devadesátých letech 19. století), tak se stávkami dělníků (zvláště v roce 1903). Ovšem nikoli ve smyslu jejich tvrdého potlačení. I v tom se projevila míra Pleveho konzervativního konstruktivismu. Pleve se totiž snažil stávkové hnutí podchytit tím, že zapojoval do jeho organizace stát, resp. některé jeho instituce. Znamenalo to organizování dělnických spolků za policejní účasti, kde policie spolupracovala s vedením takových uskupení. Někdy také policie sama organizovala dělnické stávky či stát financoval některé dělnické aktivity. Jednalo se např. o vydávání tiskovin, zdánlivě protistátních, zaměřených na dělnictvo, přičemž se měla nasměrovat obecná nespokojenost směrem od vlády k „vnitřnímu nepříteli“, za něhož byli označováni zejména Židé.

V očích tehdejšího západního i současného civilizovaného světa se Pobědonoscev i Pleve jeví jako osoby negativní. Je tomu zejména proto, že v době jejich působení bylo utuženo samoděržaví a došlo k zesílení represí proti odpůrcům carismu. V Rusku dokonce posílila reakce a došlo k silné rusifikaci, zejména v periferních guberniích. Nastalo také vyvrcholení antisemitismu. Jak jsme ale viděli, protižidovské pogromy jimi nebyly podporovány, nýbrž spíše tolerovány. Jejich zásahem byla omezena svoboda tisku, utužena cenzura knih a prosazen zákaz filozofických a jiných státovědných studií, byla zrušena univerzitní autonomie, vyšší školství bylo podřízeno pravoslavné církvi, ale jen proto, aby se zabránilo nekontrolovatelnému šíření liberálních a revolučních vizí. Pobědonoscev i Pleve byli velmi vzdělaní muži, absolventi práv. Pobědonoscev je pokládán za jednoho z nejvzdělanějších právníků 19. století. Jeho třísvazková Učebnice občanského práva je významným přispěním v oblasti práva. Jednou z kladných stránek je jeho podpora kultury. Z let 1881-1886 se dochovalo pět dopisů adresovaných Pobědonoscevovi Petrem Iljičem Čajkovským, ve kterých ho Čajkovskij nejprve žádal o podporu tří tisíc rublů a poté mu poděkoval za obdrženou sumu. Pobědonoscev se pravděpodobně přimluvil u cara, který poté v roce 1888 daroval Čajkovskému tři tisíce rublů jako roční penzi. ${ }^{13}$ Pobědonoscev také poskytoval finanční podporu botanikovi a hudebníkovi Sergeji Rachinskemu, který hodně psal o náboženství, umění a literatuře. Zajímavá je předmluva v anglickém vydání

13 http://en.tchaikovsky-research.net/pages/Konstantin_Pobedonostsev. Staženo 1. 7. 2014. 
Pobědonoscevova díla Moskevský sbornik. Jeho autorka, ruská historička Olga Novikovová v ní tvrdí, že přesto, že jsou Pobědonoscevovy myšlenky odmítány jako středověké a Pobědonoscev je většinou líčen jako despota a tmář, který uvrhl Rusko o sto let zpět, nikdo nemůže upřít, že vždy jednal podle nejvznešenějších principů, jak politických, tak náboženských. Své rozsudky prý vynášel zarytě a neústupně, jednal ale jako zásadový muž. I jeho největší nepřátelé nemohou popřít, že z jeho díla dýchá upřímnost, otevřenost a čestnost. Lidé, kteří ho odmítají, by ho prý měli vzít na vědomí a respektovat, protože to byl muž principů, zastával obdivuhodnou pozici ve světovém impériu, jako bylo Rusko, a svým vzděláním, charakterem a nepoddajností si vydobyl přední pozici na carském dvoře. ${ }^{14}$ Jistě se v tom všem projevuje závan konzervatismu, který byl Pobědonoscev, stejně jako Pleve ochoten nejen akceptovat, ale i v ruském prostředí rozvíjet.

Západoevropský konzervatismus byl důslednou reakcí na Velkou francouzskou revoluci. Tvrdí se, že ruský konzervatismus takovouto reflexí neprošel, a tudíž se konstituoval pomalu a zvláštním způsobem. Ve skutečnosti ale revoluční reflexí prošel, a to hned dvakrát: reflexí na Velkou francouzskou revoluci v pojetí Karamzina - pojetí, které v ruské společnosti ještě nenašlo výraznější odezvu; a poté reflexí na reformy Alexandra II. v pojetí Pobědonosceva a Pleveho. Z ruského pohledu se zrušení nevolnictví, zavedení správního systému v podobě zemstev a městských dum a řada dalších reforem jevily jako dramatická změna, která mění mentalitu společnosti, její orientaci a každodenní život. Následný nástup anarchismu a terorismu se zdál být negativní reakcí na proběhlá „uvolnění“ a tudíž nutně vedl k zamyšlení intelektuálů a politiků, zda liberalizující kroky cara Alexandra II. byly rozumné. Závěr, že jedině konzervativní postup - nikoli apriorní vyvarování se změn, ale jejich postupná příprava za důsledného dohledu státu je jediným možným východiskem, se jevil jako logický. Vjačeslav Konstantinovič Pleve stejně jako Konstantin Petrovič Pobědonoscev dobře znali politické a společenské myšlení západu. $\mathrm{V}$ lecčems se vůči němu vyhraňovali, ale také jej v lecčems napodobovali. Skutečnost, že byli důslednými zastánci tradičního principu samoděržaví ve všech oblastech ruského života, v záležitostech kultury, politiky i správy, a to i na místní úrovni, nebyla dramaticky vzdálena západnímu konzervativnímu důrazu na stát. Společným jmenovatelem jejich postojů bylo důsledné nadřazování nacionálně pojatého impéria všem ostatním zájmům, jmenovitě zájmům obyvatelstva, a poslušnost carovi jakožto hlavní morální kritérium. Ani to se od západoevropského konzervativního myšlení př́liš nelišilo. Řád a pořádek jim byly nejvyšší metou. Skedova práce o britském konzervatismu počátku 19. století je nepochybně velkou inspirací pro identifikování kořenů moderního konzervativního myšlení i v jiných zemích. Dokonce i v Rusku, o němž bychom se mohli domnívat, že v něm moderní konzervatismus jako politické myšlení a politická doktrína vůbec nezakořenily.

14 Pobedonostsev, K. P.: Reflections of a Russian Statesman. Published by G. Richards, 1898. In: http://www. archive.org/details/reflectionsofrus00pobeuoft. Staženo 1. 7. 2014. 


\section{Russia Conservatism at the Turn of the 19th and 20th Centuries}

This study focuses on the issue of Russian conservatism at the turn of the 19th and 20th centuries. The author works in a multifaceted way with Alan Sked's work on British conservatism in the early 19th century and points out that the conclusions which Sked outlined for the British setting can also to some extent be applied elsewhere, specifically to the setting of the Russian Empire. He does not assert that East and West are the same, but he attempts to show that trends similar to those which unfolded in the Western European setting, within the framework of the global intellectual conservative world, also gained ground in the East, even though they may be differentiated by the time when they occurred. The author demonstrates that there were also individuals in Russia at the turn of the 19th and 20th centuries who found a solution to the Russian crisis in a conservative perspective (not unlike British conservatism of the early 19th century) and that Russian conservative thought went through an important process of reflection in response to the phenomenon of revolution. This initially happened in response to the French Revolution (Nikolay M. Karamzin) and then in response to the "revolutionary" reforms of Alexander II (Konstantin Petrovich Pobedonostsev, Vyacheslav Konstantinovich Pleve). 
